\title{
Pharmaceutico-Analytical standardization of 60 Puti Abhraka Bhasma
}

\author{
Research Article
}

\section{Krupali Jani1 $^{*}$, Prashant Bedarkar ${ }^{2}$, Shukla V J33, Patgiri B J4}

\author{
1. Ph.D Scholar, 2. Associate Professor, 4. Professor and Head, \\ RasaShastra and Bhaishajya Kalpana Department, \\ 3. Head, Pharmaceutical Chemistry, \\ I.P.G.T.\&R.A, Gujarat Ayurved University, Jamnagar 361008, Gujarat.
}

\begin{abstract}
Abhraka Bhasma comes under Maharasa Varga and after Parada second position hold by Abhraka. From centuries, Acharayas have been using Abhraka Bhasma incorporated in vast number of formulations. There are so many methods and medias is used for Shodhana,Marana process of Abhraka, in present study for Abhraka Shodhana, Godugdha is used as Shodhana media followed by,Dhanyabhraka and for Marana Gomutra is used. Aim: To generate pharmaceutical and analytical profile of 60 Puti Abhraka Bhasma Material \& methods: Abhraka Shodhana was done by quenching Abharaka in Godugdha followed by Dhanyabhraka in Kanji later subjected to Puta using Gomutra as liquid media.Physcio- chemical parameters of Bhasma is performed as per API. Discussion: Different critical aspects of Abhraka Bhasma will be discussed while increasing number of Puta Conclusion: 60 Puti Abhraka Bhasma dull brown in color and passed all the classical and modern parameters.
\end{abstract}

Key Words: Abhraka, Bhasma, Calcination, Gomutra, Marana, Shodhana.

\section{Introduction}

The Ayurveda is the traditional system of medicine which is been used by Indian's. The science of life is the basic meaning of the word Ayurveda. The treatment of mica (Biotite) with that of medicinal agents is the basic method of preparing the Bhasma. Since ancient times Abhraka Bhasma were used as an Ayurvedic medicine to cure various disease such as asthma, Tuberculosis, cancer, Hepatic dysfunction, Diabetic and so on. The toxicity of the minerals has been shown only when excess dose of material is given. Abhraka Bhasma the oxide form of the minerals are poorly soluble and hence not in free form which has been shown by acute toxicity study $5000 \mathrm{mg} / \mathrm{kg} \mathrm{BW}$ is safe in the wister rats of both sex. (1) Bhasma is a minute dosage form of drug (especially metals and minerals) which intake is not possible in raw form. So it is required to be converted into palatable form by various processes like Shodhana and Marana. One more advantage of Bhasma Kalpana is that it has very long shelf life compared to other dosage forms and it can give best therapeutic effect at very small dose.(2) Shodhana of drug is necessary to remove harmful and ill effects of drug for better consumption. In case of Abhraka, Shodhana plays very important role not only for size

* Corresponding Author:

\section{Krupali Jani}

Ph.D Scholar,

Rasa Shastra and Bhaishajya Kalpana Department,

I.P.G.T.\&R.A, Gujarat Ayurved University,

Jamnagar 361008, Gujarat. India.

Email Id: krupali.jani04@gmail.com reduction but also to remove silica-silicates and other fat soluble impurities from Abhraka by doing Shodhana in Godugdha. After Shodhana Dhanyabhraka Nirmana is done which is a very important event takes place before subjecting the Abhraka for Puta. In ayurvedic various Marana methods has been mentioned but in this study marana with single liquid media was done i.e. Gomutra. It is also mentioned in texts as no. of Puta increases its therapeutic value aslo increases. The number of Putas described for Abhraka are from 1 to 1000 which is very significant than any other Bhasma. As no. of Puta increases Bhasma starts working as Nano particle, Bhasma should pass all the examination which is mentioned in the text if Bhasma will not pass test then it is not prepared, among all examination Nishchantartva is one of the important examination for Abhraka Bhasma if there is lusture in Bhasma then it still need to subjected for Puta there are some other examinations also for conforming whether Bhamsa is prepared properly 0of not i.e Sukhma, Slakshna, Dantagrahakachkachaabhava, Nirutha, Apunarbhava Vaitaratva, Unama etc.(3) In the present study prime goal is to cover all the pharmaceutical aspects of Bhasma preparation and what all points to be taken under consideration when prepared as tested as per classical methods. So far, no detailed description of pharmaceutical preparation of Abhraka Bhasma is carried out. Repeated calcination at $900{ }^{\circ} \mathrm{C}$ in electric muffle furnace to achieve its Bhasma. Conventional Puta resulting in to oxidation and micronization of substance, which makes the finished product in edible form having increased bioavailability, therapeutic characteristics and devoid of toxic feature. 


\section{Materials and Methods}

\section{Collection of materials}

Ashuddha Abhraka of acceptable quality was procured from the pharmacy of Gujarat Ayurved University, Jamnagar,Gujarat. It was authenticated for Grahya Lakshana as per Classical and modern methods. (4)

For Shodhana process, Godugdha was purchased from shreeji goras dairy, Jamnagar. For Dhanyabhraka Nirmana, Shali dhanya was purchased from local market of Jamnagar. For Marana process, fresh Gomutra was collected from panjrapol Gaushala, Jamnagar, Gujarat.

Table 1: Showing Observations and Results during Abhraka Shodhana

\begin{tabular}{|c|c|c|c|c|c|c|c|c|c|}
\hline & \multirow{2}{*}{$\begin{array}{c}\text { Nirvapa } \\
\text { no. }\end{array}$} & \multirow{2}{*}{$\begin{array}{l}\text { Duration required } \\
\text { to achieve red hot } \\
\text { stage (min) }\end{array}$} & \multirow{2}{*}{$\begin{array}{c}\text { Quenching } \\
\text { time/ Soaking } \\
\text { duration (min) }\end{array}$} & \multicolumn{3}{|c|}{ Wt. Changes in Abhraka } & \multicolumn{3}{|c|}{ Media volume changes } \\
\hline & & & & Initial (g) & After (g) & $\begin{array}{c}\% \\
\text { Change }\end{array}$ & $\begin{array}{c}\text { Initial } \\
(\mathrm{ml})\end{array}$ & $\begin{array}{c}\text { After } \\
(\mathrm{ml})\end{array}$ & $\begin{array}{c}\% \\
\text { change }\end{array}$ \\
\hline \multirow{7}{*}{ Batch 1} & $1 \mathrm{st}$ & 26 & 5 & 1500 & 1600 & $6.6 \uparrow$ & 2500 & 1700 & $32 \downarrow$ \\
\hline & 2nd & 44 & 5 & 1600 & 1696 & $6 \uparrow$ & 2500 & 1500 & $40 \downarrow$ \\
\hline & $3 \mathrm{rd}$ & 35 & 7 & 1696 & 1635 & $3.5 \downarrow$ & 3000 & 2100 & $30 \downarrow$ \\
\hline & 4th & 28 & 6 & 1635 & 1689 & $3.3 \uparrow$ & 3000 & 2000 & $33 \downarrow$ \\
\hline & 5 th & 25 & 5 & 1689 & 1655 & $2.1 \downarrow$ & 3000 & 2000 & $33 \downarrow$ \\
\hline & 6th & 22 & 5 & 1655 & 1589 & $3.9 \downarrow$ & 3000 & 2000 & $33 \downarrow$ \\
\hline & 7th & 30 & 11 & 1589 & 1515 & $4.6 \downarrow$ & 3000 & 1800 & $40 \downarrow$ \\
\hline \multirow{7}{*}{ Batch 2} & $1 \mathrm{st}$ & 35 & 5 & 1500 & 1927 & $28.4 \uparrow$ & 2500 & 1500 & $40 \downarrow$ \\
\hline & 2nd & 32 & 5 & 1927 & 1973 & $2.5 \uparrow$ & 2500 & 1510 & $39.6 \downarrow$ \\
\hline & $3 \mathrm{rd}$ & 25 & 7 & 1973 & 1979 & $1.8 \uparrow$ & 3000 & 2150 & $28.3 \downarrow$ \\
\hline & 4th & 13 & 6 & 1979 & 1969 & $0.2 \uparrow$ & 3000 & 2150 & $28.3 \downarrow$ \\
\hline & 5 th & 13 & 5 & 1969 & 1885 & $1 \uparrow$ & 3000 & 2000 & $33.3 \downarrow$ \\
\hline & 6th & 14 & 5 & 1885 & 1885 & $1.4 \uparrow$ & 3000 & 2150 & $28.3 \downarrow$ \\
\hline & 7th & 14 & 9 & 1885 & 1960 & $3.9 \uparrow$ & 3000 & 2050 & $31.6 \downarrow$ \\
\hline \multirow{7}{*}{ Batch 3} & $1 \mathrm{st}$ & 40 & 5 & 1500 & 1950 & $30 \uparrow$ & 2500 & 1750 & $30 \downarrow$ \\
\hline & 2nd & 35 & 5 & 1950 & 1900 & $2.5 \uparrow$ & 2500 & 1700 & $32 \downarrow$ \\
\hline & $3 \mathrm{rd}$ & 25 & 7 & 1900 & 1936 & $1.8 \uparrow$ & 2500 & 1625 & $35 \downarrow$ \\
\hline & 4th & 15 & 6 & 1936 & 1940 & $0.2 \uparrow$ & 2500 & 1650 & $34 \downarrow$ \\
\hline & 5th & 15 & 5 & 1940 & 1960 & $1 \uparrow$ & 3000 & 2000 & $33 \downarrow$ \\
\hline & 6th & 14 & 5 & 1960 & 1988 & $1.4 \uparrow$ & 3000 & 2100 & $30 \downarrow$ \\
\hline & 7th & 15 & 9 & 1988 & 1924 & $3.2 \downarrow$ & 3000 & 2000 & $33 \downarrow$ \\
\hline \multirow{7}{*}{ Batch 4} & $1 \mathrm{st}$ & 40 & 5 & 1500 & 1955 & $30.3 \uparrow$ & 2500 & 1750 & $30 \downarrow$ \\
\hline & 2nd & 35 & 5 & 1955 & 1960 & $0.2 \uparrow$ & 2500 & 1700 & $32 \downarrow$ \\
\hline & $3 \mathrm{rd}$ & 25 & 7 & 1960 & 1939 & $1.07 \downarrow$ & 2500 & 1500 & $40 \downarrow$ \\
\hline & 4th & 20 & 6 & 1939 & 1950 & $0.5 \uparrow$ & 3000 & 2150 & $28.3 \downarrow$ \\
\hline & 5th & 15 & 5 & 1950 & 1955 & $0.2 \uparrow$ & 3000 & 2000 & $33 \downarrow$ \\
\hline & 6th & 14 & 5 & 1955 & 1980 & $1.2 \uparrow$ & 3000 & 2100 & $30 \downarrow$ \\
\hline & 7th & 14 & 9 & 1980 & 1920 & $3.0 \downarrow$ & 3000 & 2200 & $26.6 \downarrow$ \\
\hline
\end{tabular}

Table 2: Showing Comparison of 4 batches Shodhana

\section{Parameter}

Total duration of Nirvapa

Avg. duration for red hot stage (min)

Avg. soaking time (min)

Final dry weight of $A b h r a k a(g)$

Avg. loss of media (\%)

Avg. temp. of vessel during red hot stage $\left({ }^{\circ} \mathrm{C}\right)$

Avg. temp. of hearth during red hot stage $\left({ }^{\circ} \mathrm{C}\right)$

Avg. temp. of milk during quenching $\left({ }^{\circ} \mathrm{C}\right)$

Change in the total wt. of Abhraka (\%)

Loss in the wt. of Abhraka after last heating (\%)

Average yield of Abhraka (\%)

\section{Preparation of Dhanyabhraka(6)}

Shuddha Abhraka and 1/4th quantity of Shali Dhanya were mixed properly \& filled in a jute bag Then Pottali was made by tying the jute bag. It was immersed in S.S vessel filled with Kanji \& kept undisturbed for

\section{Pharmaceutical study}

It is divided in four different stages;

- Shodhana of Abhraka

- Preparation of Dhanyabhraka

- Preparation of Abharka marana

\section{Shodhana of Abhraka (5)}

For Shodhana, Ashuddha Abhraka was heated in iron pan until it became red hot. Then it was quenched (Nirvap) in Godugdha taken in s.s vessel as liquid media.It was again heated until red hot state and same process was repeated for 7 times. 
International Journal of Ayurvedic Medicine, Vol 12 (2), 360-365

Table 3: Ingredients with quantity

\begin{tabular}{|c|c|c|}
\hline Sr.no & Ingredients & Quantity \\
\hline 1 & Shudhha Abhraka & $5.013 \mathrm{~g}$ \\
2 & Shali Dhanya & $1.35 \mathrm{~g}$ \\
3 & Kanji & Q.S $(20 l)$ \\
\hline
\end{tabular}

Table 4: Showing Results and Observation of Abharaka Marana

\begin{tabular}{|c|c|c|c|c|c|}
\hline $\begin{array}{c}\text { No. } \\
\text { of } \\
\text { Puta }\end{array}$ & $\begin{array}{c}\text { Initial } \\
\text { weight of } \\
\text { Abharaka } \\
\quad(g)\end{array}$ & $\begin{array}{c}\text { Liquid } \\
\text { media } \\
\text { (Gomutra) } \\
\text { used for } \\
\text { Bhavana } \\
(\mathrm{ml})\end{array}$ & $\begin{array}{l}\text { Weight of } \\
\text { Chakrika } \\
\text { after } \\
\text { drying } \\
(\text { g) }\end{array}$ & $\begin{array}{l}\text { Weight } \\
\text { of } \\
\text { Chakrika } \\
\text { after } \\
\text { Puta } \\
\text { (g) }\end{array}$ & $\begin{array}{c}\text { Increase } \\
\text { of wt. } \\
\text { after } \\
\text { Bhavana } \\
\text { (\%) }\end{array}$ \\
\hline 1 & 4.404 & 7000 & 4.608 & 4.395 & 4.63 \\
\hline 2 & 4.395 & 5000 & 4.612 & 4.373 & 4.93 \\
\hline 3 & 4.373 & 2800 & 4.595 & 4.350 & 5.07 \\
\hline 4 & 4.350 & 2400 & 4.652 & 4.352 & 6.94 \\
\hline 5 & 4.352 & 2400 & 4.553 & 4.321 & 4.41 \\
\hline 6 & 4.321 & 2200 & 4.521 & 4.320 & 4.62 \\
\hline 7 & 4.320 & 2200 & 4.525 & 4.351 & 4.74 \\
\hline 8 & 4.351 & 2400 & 4.551 & 4.345 & 4.59 \\
\hline 9 & 4.345 & 2400 & 4.545 & 4.347 & 4.60 \\
\hline 10 & 4.347 & 2200 & 4.550 & 4.341 & 4.66 \\
\hline 11 & 4.341 & 2200 & 4.542 & 4.342 & 4.63 \\
\hline 12 & 4.342 & 2200 & 4.556 & 4.339 & 4.92 \\
\hline 13 & 4.339 & 2200 & 4.546 & 4.337 & 4.77 \\
\hline 14 & 4.337 & 2400 & 4.538 & 4.332 & 4.63 \\
\hline 15 & 4.332 & 2200 & 4.540 & 4.330 & 4.80 \\
\hline 16 & 4.330 & 2200 & 4.532 & 4.300 & 4.66 \\
\hline 17 & 4.300 & 2200 & 4.515 & 4.312 & 5 \\
\hline 18 & 4.312 & 2200 & 4.520 & 4.305 & 4.82 \\
\hline 19 & 4.305 & 2200 & 4.507 & 4.300 & 4.69 \\
\hline 20 & 4.300 & 2200 & 4.505 & 4.310 & 4.76 \\
\hline 21 & 4.310 & 2000 & 4.520 & 4.291 & 4.87 \\
\hline 22 & 4.291 & 2000 & 4.500 & 4.290 & 4.89 \\
\hline 23 & 4.290 & 2000 & 4.495 & 4.288 & 4.87 \\
\hline 24 & 4.288 & 2000 & 4.488 & 4.283 & 4.66 \\
\hline 25 & 4.283 & 2000 & 4.483 & 4.271 & 4.66 \\
\hline 26 & 4.271 & 2000 & 4.473 & 4.250 & 4.72 \\
\hline 27 & 4.250 & 2000 & 4.502 & 4.255 & 5.92 \\
\hline 28 & 4.255 & 2000 & 4.455 & 4.231 & 4.70 \\
\hline 29 & 4.231 & 2000 & 4.432 & 4.232 & 4.75 \\
\hline 30 & 4.232 & 2000 & 4.435 & 4.220 & 4.79 \\
\hline 31 & 4.220 & 2000 & 4.520 & 4.212 & 7.10 \\
\hline 32 & 4.212 & 2000 & 4.462 & 4.205 & 5.93 \\
\hline 33 & 4.205 & 1900 & 4.490 & 4.159 & 6.77 \\
\hline 34 & 4.159 & 1900 & 4.430 & 4.145 & 6.51 \\
\hline 35 & 4.145 & 1900 & 4.395 & 4.105 & 6.03 \\
\hline 36 & 4.105 & 1800 & 4.315 & 4.101 & 5.11 \\
\hline 37 & 4.101 & 1800 & 4.308 & 4.095 & 5.04 \\
\hline 38 & 4.095 & 1800 & 4.298 & 4.090 & 4.95 \\
\hline 39 & 4.090 & 1800 & 4.290 & 4.085 & 3.29 \\
\hline 40 & 4.085 & 1800 & 4.291 & 4.072 & 5.04 \\
\hline 41 & 4.072 & 1700 & 4.272 & 4.070 & 4.91 \\
\hline 42 & 4.070 & 1700 & 4.273 & 4.061 & 4.98 \\
\hline 43 & 4.061 & 1700 & 4.250 & 4.051 & 4.65 \\
\hline 44 & 4.051 & 1700 & 4.225 & 4.052 & 4.29 \\
\hline 45 & 4.052 & 1700 & 4.220 & 3.995 & 4.41 \\
\hline 46 & 3.995 & 1700 & 4.100 & 3.995 & 2.62 \\
\hline 47 & 3.995 & 1700 & 4.105 & 3.993 & 2.73 \\
\hline 48 & 3.993 & 1700 & 4.115 & 3.990 & 3.05 \\
\hline 49 & 3.990 & 1700 & 4.103 & 3.991 & 2.83 \\
\hline 50 & 3.991 & 1700 & 4.125 & 3.992 & 3.35 \\
\hline 51 & 3.992 & 1700 & 4.120 & 3.990 & 3.20 \\
\hline 52 & 3.990 & 1800 & 4.123 & 3.992 & 3.22 \\
\hline 53 & 3.992 & 1700 & 4.120 & 3.990 & 3.20 \\
\hline 54 & 3.990 & 1800 & 4.124 & 3.993 & 3.35 \\
\hline 55 & 3.993 & 1800 & 4.115 & 3.992 & 3.05 \\
\hline 56 & 3.992 & 1800 & 4.126 & 3.989 & 3.35 \\
\hline 57 & 3.989 & 1700 & 4.119 & 3.989 & 3.25 \\
\hline 58 & 3.989 & 1700 & 4.115 & 3.985 & 3.15 \\
\hline 59 & 3.985 & 1700 & 4.120 & 3.983 & 3.38 \\
\hline 60 & 3.983 & 1700 & 4.128 & 3.983 & 3.64 \\
\hline
\end{tabular}

\section{Preparation of Abhraka Bhasma (7)}

Shuddha Abhraka was taken in end runner and Gomutra was added in sufficient quantity for levigation (Bhavana) till mass became soft. Chakrikas were prepared and allowed to dry. Then it was kept in Sharava (earthen saucer) and covered with another Sharava. Average weight of 10 Chakrika before Puta was $15.1 \pm 0.7$.After proper drying, it was subjected to Puta in electric muffle furnace (EMF) having temperature upto $900^{\circ} \mathrm{C}$. After attaining optimum temperature i.e. $900^{\circ} \mathrm{C}$, it was further maintained for one hour and then furnace was switched off. On selfcooling i.e. Swangasheeta, material was taken out from furnace and weighed. Hardness was noted with the help of hardness tester. (8) Again puta was given in the same manner and repeated for 60 times. Same temperature pattern was followed for every Puta. Observations were noted and samples of Abhraka Bhasma were collected after 10,20,30,40 and 60 Puta. (Graph 1)

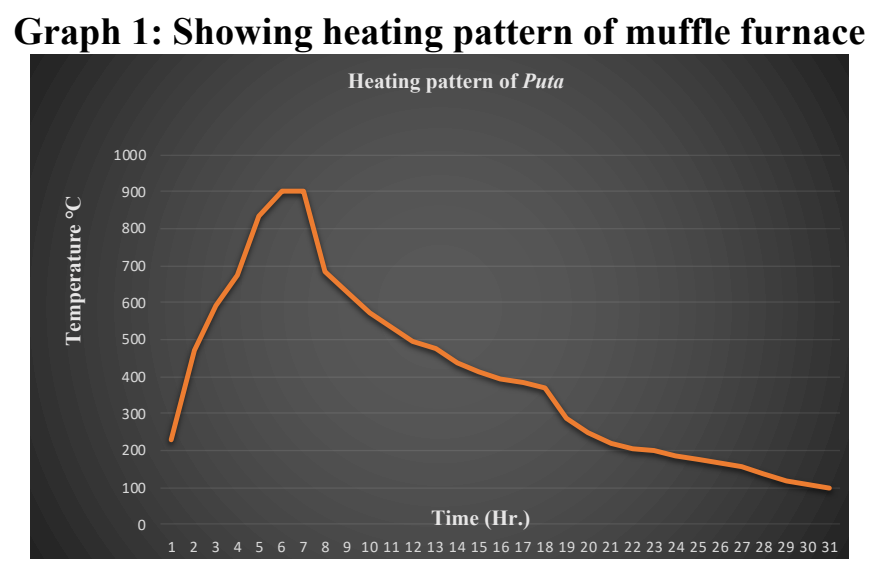

Table 5: Showing the complete Marana process of Abhraka Bhasma

Total number Temperature Number of days Duration of \begin{tabular}{|c|c|c|c|}
\hline of Puta & ${ }^{\circ} \mathrm{C}$ & During one Puta & levigation \\
\hline 60 & 900 & 3 days & $3 \mathrm{hrs} /$ Puta \\
\hline
\end{tabular}

Table 6: Showing Results of Bhasmapariksha and hardness of Abhraka Bhasma

\begin{tabular}{|c|c|c|c|c|}
\hline Puta & $\begin{array}{c}\text { Rekha- } \\
\text { purnatva }\end{array}$ & $\begin{array}{c}\text { Nish- } \\
\text { chandratva }\end{array}$ & $\begin{array}{c}\text { Vari- } \\
\text { taratva }\end{array}$ & Hardness \\
\hline 1 to 5 & - & - & - & 14 \\
\hline 6 to 10 & + & - & - & 13 \\
\hline 11 to 15 & + & - & - & 12 \\
\hline 16 to 20 & + & - & - & 8 \\
\hline 21 to 25 & + & - & - & \multirow{2}{*}{ H } \\
\hline 26 to 30 & + & - & - & 6 \\
\hline 31 to 35 & + & + & + & 5 \\
\hline 36 to 40 & + & + & + & \\
\hline 41 to 45 & + & + & + & 3 \\
\hline 46 to 50 & + & + & + & \\
\hline 51 to 55 & + & + & + & \\
\hline 56 to 60 & + & + & + & \\
\hline
\end{tabular}

Table 7: Showing Results of Classical parameters to assess Abhraka Bhasma

\begin{tabular}{|c|c|c|}
\hline Sr.no & Bhasma Pariksha & Observation \\
\hline 1 & Nishchandratv & Passed \\
\hline 2 & Rekhapurnatva & Passed \\
\hline 3 & Varitaratva & Passed \\
\hline 4 & Unam & Passed \\
\hline
\end{tabular}


Krupali Jani et.al., Pharmaceutico-Analytical standardization of 60 Puti Abhraka Bhasma

\begin{tabular}{|l|c|c|}
\hline 5 & Dantagrekachkachabhava & Passed \\
\hline 6 & Apunarbhava & Passed \\
\hline 7 & Niruthha & Passed \\
\hline
\end{tabular}

FIGURE : 1

PHARMACEUTICAL PROCESING OF ABHRAKA BHASMA
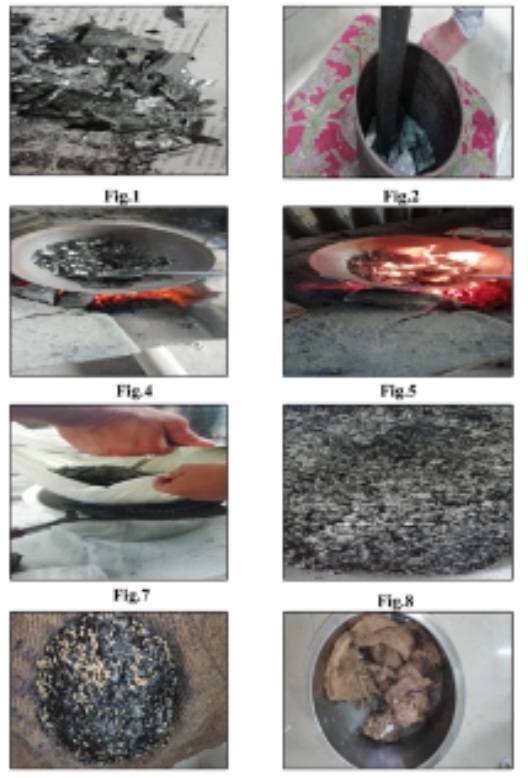

Fis.10
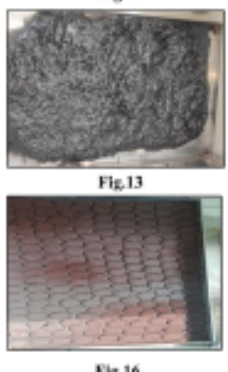

Fe.16
Fing 5

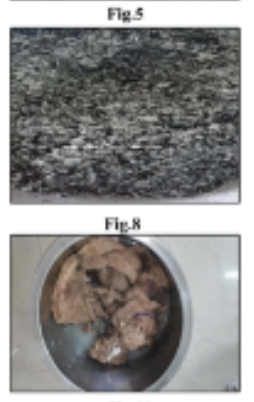

Fin.11

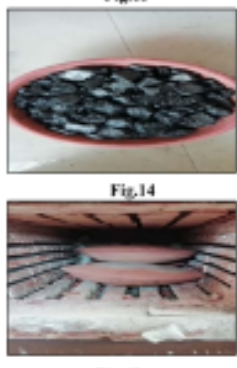

Ple17
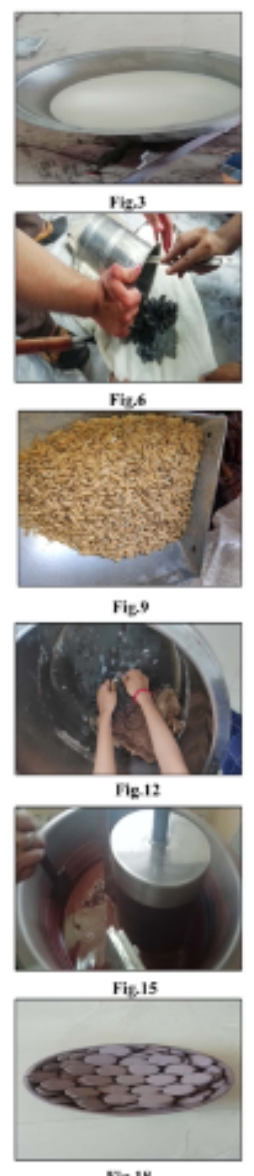

Phamaceutical steps of Abhraka Bhasma preparation

Fig. 1: Pieces of Ashuddha Abhraka

Fig.2: Poundung of Abhraka into small pieces

Fig.3: Boiling of Gdugdha for Abhraka Shodhana

Fig.4: Heating of Ashudha Abhraka

Fig.5: Abhraka become red hot

Fig.6 \& Fig.7: Quenching of Abhraka in Godugdha and separating Godugdha from Abhraka

Fig.8: Shodhit Abhraka

Fig.9: Dhanya for Dhanyabhraka

Fig.10: Mixing of Dhanya and Shodhit Abhraka

Fig.11: Dipping Pottali of Dhanyabhrakain Kanji for 3 days

Fig.12: Maceration of Pottali to obtain fne particles of Abhraka

Fig. 13: Processed Abhraka

Fig.14: For Puta, Abhraka in Sarava

Fig.15: Bhavana of Gomuta in Abhraka

Fig.16: Chrakrika Nirmana

Fig. 17: Kept in horizontal muffle furnace

Fig.18: Abhraka Bhasma after Puta

\section{Analytical study}

i.Determination of $\mathrm{pH}(9)$

ii.Determination of specific gravity(10)

iii.Determination of Total solid content(11)

iv.Determination of Loss on drying(12)

v.Determination of Ash value(13)

vi.Determination of Acid insoluble ash(14)

Table 8: Showing Results of Analytical parameters of the Nirvapa media (Godugdha)

\begin{tabular}{|c|c|c|c|c|c|c|c|c|}
\hline & \multicolumn{7}{|c|}{ Nirvapa } \\
\hline Parameters & $\begin{array}{c}\text { Bef } \\
\text { ore }\end{array}$ & $\mathbf{1}^{\text {st }}$ & $\mathbf{2}^{\text {nd }}$ & $\mathbf{3}^{\text {rd }}$ & $\mathbf{4}^{\text {th }}$ & $\mathbf{5}^{\text {th }}$ & $\mathbf{6}^{\text {th }}$ & $7^{\text {th }}$ \\
\hline Ph & 9.8 & 9.5 & 9.7 & 9.6 & 9.6 & 9.5 & 9.5 & 9.5 \\
\hline $\begin{array}{c}\text { Specific } \\
\text { gravity }\end{array}$ & 1.034 & 1.038 & 1.037 & 1.037 & 1.036 & 1.036 & 1.038 & 1.041 \\
\hline $\begin{array}{c}\text { Total solid } \\
\text { content }\end{array}$ & 20.088 & 15.796 & 19.728 & 19.892 & 20.316 & 20.16 & 21.644 & 34.804 \\
\hline
\end{tabular}

Table 9: Showing Results of Analytical parameters of the of Gomutra

\begin{tabular}{|c|c|c|c|c|}
\hline Sr.no & Sample & $\mathbf{p H}$ & $\begin{array}{c}\text { Specific } \\
\text { gravity }\end{array}$ & $\begin{array}{c}\text { Total solid } \\
\text { content }\end{array}$ \\
\hline 1 & Gomutra & 8.5 & 1.0150 & 1.408 \\
\hline
\end{tabular}

Table 10: Showing Results of Organoleptic characteristics of Abhraka Bhasma

Appearance (Rupa) Fine powder Colour (Varna) Dull brown

Touch (Sparsha) Smooth

Smella (Gandha) Not Specific

Table 11: Showing Results of physico- chemical parameters of Abhraka

\begin{tabular}{|c|c|c|c|c|}
\hline Sr.no & Sample & $\begin{array}{c}\text { Loss on } \\
\text { drying }\end{array}$ & Ash value & $\begin{array}{c}\text { Acid } \\
\text { insoluble } \\
\text { ash }\end{array}$ \\
\hline 1 & $\begin{array}{c}\text { Ashodhita } \\
\text { Abhraka }\end{array}$ & 0.06 & 96.98 & 42.55 \\
\hline 2 & $\begin{array}{c}\text { Shodhita } \\
\text { Abhraka }\end{array}$ & 0.09 & 99.33 & 32.05 \\
\hline 3 & $\begin{array}{c}\text { Dhanya } \\
\text { Abhraka }\end{array}$ & 0.08 & 82.96 & 38.24 \\
\hline 4 & $\begin{array}{c}\text { After 10 } \\
\text { Puta }^{\text {th }}\end{array}$ & 0.05 & 86.50 & 36.25 \\
\hline 5 & $\begin{array}{c}\text { After 20 } \\
\text { Puta }\end{array}$ & 0.07 & 91.25 & 43.35 \\
\hline 6 & $\begin{array}{c}\text { After 40 } \\
\text { puta }\end{array}$ & 0.08 & 96.97 & 31.25 \\
\hline 7 & $\begin{array}{c}\text { After 60 } \\
\text { Puta }\end{array}$ & 0.09 & 99.57 & 41.12 \\
\hline
\end{tabular}

Table 12: Showing Results of Qualitative test for presence of silicates in Abhraka Bhasma(15)

\begin{tabular}{|c|c|c|c|}
\hline Sr.no & Puta & $\begin{array}{c}\text { Presence of } \\
\text { silicate }\end{array}$ & Confirmatory test \\
\hline 1 & 10 & ++ & $\begin{array}{c}\text { White color } \\
\text { precipitate were } \\
\text { observed which }\end{array}$ \\
\hline 2 & 20 & ++ & $\begin{array}{c}\text { shows the presence of } \\
\text { silicates }\end{array}$ \\
\hline 3 & 40 & ++ & s. \\
\hline 4 & 60 & ++ & \\
\hline
\end{tabular}

\section{Discussion}

Abhraka Bhasma is mentioned in various disease conditions like Jwara,Sannipata, Prameha, Grahni, Swasa, Kasa, Rajyaskshma, Hridyaroga,etc. (16) Although for the preparation of Abhraka Bhasma numerous methods have been mentioned in texts of Ayurveda, but method of preparation is same i.e Shodhana (purification), Dhanyabhrakaand Marana(calcination). Every Bhasma has some specific properties, but Bhawna dravya explore synergistic effect for some particular properties.(17) Rasa classics say that quality of Bhasma increased with number of 
Puta (18) and it was also observed in a study that particle size of Bhasma decreases with increase in number of Puta (19), which increase the potency of Bhasma. For preparation of Bhasma, Shodhana should be done properly to eliminate all the ill effects of Ashudha Abhraka. In Abhraka Shodhana loss of material was more compared to other Rasa Dravyas after Shodhana as the particles size reduces finer particles tends to flow in air. Abhraka was heated till it became red hot, because elements present in the Abhraka may be converted into oxide form by reacting with atmospheric oxygen (20). Further it was quenched in Godugdha \& this process was repeated (heating and cooling in liquid media) for 7 times which leads to size reduction of material. Repeated heating and cooling of Abhraka flakes causes disruption in compression tension equilibrium leads to cracks on the flake surface. (21) Particles become very fine after Shodhana process during filtration of material from media, small finer particles does not get separate out from media. It was observed that material takes more time to become red hot as the number of quenching increases. After Shodhana bulk of material increases due to removal of moisture and reduction of particle size as layers of Abhraka gets separated. At later stages of quenching required quantity of liquid media increase due to smaller particle size, more absorption of media and better exposure of material to media for effective Shodhana. Average \% yield of Abhraka after Shodhana $88.52 \%$ was obtained from four batches of Shudha Abhraka.

\section{Role of Media in Abhraka Shodhana}

Shodhana media acts as cooling agent during process. Due to change in temperature it serves as breakage of bond between the materials. In case of Abhraka when red hot material is quenched in media chemical reaction takes place which liberates hydrogen molecules.

\section{Dhanyabhraka}

After Shoadhan of Abhraka, process of Dhanyabhraka has been taken up. This process is exclusively mentioned for Abhraka that is helpful in further particle size reduction of Abhraka. Aproximately $20 l$ of kanji was prepared for the process of Dhanyabhraka. Percentage loss of Abhraka was more due to mixing of Dhanya with Abhraka \& small particles of Abhraka sticks to Dhanya. Process of rubbing of Abhraka with Dhanya in Pottali is called maceration. Removal of foreign matter (silica,stone,Dhanya) get trapped in Pottali and pure Abhraka is obtained. Abhraka Particles became so fine after Dhanyabhraka process that it floats on water. To collect them, the vessel is to be kept undisturbed for the sedimentation of Abhraka in the bottom vessel.This process reduces the elasticity and sharpness of edges of the Abhraka lamelia (22), percentage yield of Dhanyabhrka is 87.85 .

\section{Marana}

Incineration of Abhraka after Dhanyabhraka is next important process. It converts raw mineral into ash form (Bhasma) which is easily absorbable by the body and give desired therapeutic effect. In this process the metal or mineral is levigated and made into pellets (Chakrika) to provide uniform heat to material they are dried till moisture free and subjected to Puta. Quantum of heat which is to be provided is very important factor for oxidation and reduction process as well as for formation of desired compound. If the quantum of heat is more than pellets will become hard and the material may be reduced to the original form. If the quantum of heat is less proper reaction will not occur and may require more number of Puta for the formation of desired compounds. (23) The temperature and time are proportionately essential for facilitating optimum reactions to occur so that a genuine product can be obtained, hence it can be said that the heat of $900^{\circ} \mathrm{C}$ could be most important phase for preparation of a better quality of Abhraka Bhasma. Total 60 Puta were given. Due to increasing number of Puta hardness of Chakrika was decreasing gradually and liquid media used for Bhavana was also decreased, 9.5\% loss from $1^{\text {st }}$ Puta to $60^{\text {th }}$ Puta.At 30 Puta Chandrika was not seen through naked eyes. And after Marana Average percentage yield Abhraka Bhasma was 4.177 \pm 0.1456 . Bhasma passed all required classical test parameters i.e Nishchandratv (lustureless), Rekhapurnatva (furrow filling), Varitaratva (float on water), Unam, Dantagrekachkachabhava (Granniness), Apunarbhava (Irretrievable), Niruthha.

\section{Analytical parameters}

All parameters mentioned in tables are used as indices to illustrate the quality as well as the purity of the medicine. Liquid media used for Shodhana i.e Godugdha, $\mathrm{pH}$ was basic after every quenching from 1to 7 . $\mathrm{pH}$, specific gravity and total solid content was performed and it is showed in table no.8. It showed $\mathrm{pH}$ of media was basic in nature, specific gravity remained similar and total solid content of media found slightly increasing after every quenching due to micro fine particle of Abhraka was present in it which were inseparable.

Samples of Abhraka Bhasma having netutral pH. Moisture in Abhraka Bhasma was very less, ash value of samples was around $99 \%$ because Abhraka Bhasma is already in form of ash. Acid insoluble ash is the residue obtained after boiling sample in $\mathrm{HCl}$ material solubilize with $\mathrm{HCl}$ and insoluble matter like silica,silicates were measured after ignition. Presence of silicates was confirmed in samples of Abhraka Bhasma by Qualitative test.

\section{Conclusion}

Bhasma is prepared as mentioned in classics and examined by ancient and modern parameters. Total 60 times Puta was given. Shodhana is crucial process for further pharmaceutical processes.Average percentage yield of Abhraka after Shodhana was 88.52 
from four batches of Shudha Abhraka, Preparation of Dhanyabhraka states the significance of concept used in preparation of Abhraka Bhasma. Percentage yield of Dhanyabhrka was 87.85 and Gomutra is the best and appropriate media for the preparation of Abhraka bhasma. Marana Average percentage yield Abhraka Bhasma was $4.177 \pm 0.1456$. Bhasma passed all the Classical parameters (Bhasma Pariksha). The changes in physicochemical parameters before and after processing of Abhraka Bhasma were not much found variation but serves as a mean for Standardisation of mineral preparation. As number of Gajaputa increases in Bhasma therapeutic utility in management of diseases increases.

\section{References}

1. Srinivas A, Surekha PA, Kishore AS, Srinivasan M, Balakrishna MP, Neelakanta Reddy, Toxicity Profile of Abhraka Bhasmahrak And Tamar Bhasmas In Different Vehicles. J.Herbal Medicine and Toxicology, 2010. 4-2: p 189-196.

2. Vijay Malik, Drugs \& Cosmetics Act, 1940, 18th Updated Ed., Eastern Book Company, Lucknow, 2006

3. The Ayurvedic Formulary Of India, Chapter 21, Govt Of India, Ministry Of Health \& Family Welfare Department Of Indian System Of Medicine And Homeopathy, Part 1, Second Edition, New Delhi (2003).

4. Rasaratna Samuchhaya, Sidhhiprada Hindi Commentary, Published By Chaukhambha Orientalia Varanasi,First Edition 201, Chapter 2/11, p 31

5. Rasaratna Samuchhaya/,Sidhhiprada Hindi Commentary,Published By Chaukhambha Orientalia Varanasi,First Edition 2011,Chapter 2/16-17, p 32

6. Rasaratna Samuchhaya, Sidhhiprada Hindi Commentary, Published By Chaukhambha Orientalia Varanasi,First Edition 2011, Chapter 2/18, p 32

7. Bhudeb Mukerjee, Rasajalanidhi, Chaukhambha Publishers, 3 ${ }^{\text {rd }}$ Edition, 1998, Chapter 1, p 23.

8. Available From "Quality Control of Solid Dosage Form". Scribd. Retrieved 16 February 2013

9. Ayurvedic Pharmacopeia Of India; Government Of India, Ministry Of Health And Family Welfare Department Of Ayurveda, Yoga \& Naturopathy, Unani, Siddha And Homoeopathy, New Delhi 2008; E Book; Part 2; Vol 2; Appendix 3.3.

10. Ayurvedic Pharmacopeia Of India; Government Of India, Ministry Of Health And Family Welfare Department Of Ayurveda, Yoga \& Naturopathy,
Unani, Siddha And Homoeopathy, New Delhi 2008;

E Book; Part 2; Vol 2; Appendix 3.2.

11. Ayurvedic Pharmacopeia Of India; Government Of India, Ministry Of Health And Family Welfare Department Of Ayurveda, Yoga \& Naturopathy, Unani, Siddha And Homoeopathy, New Delhi 2008; E Book; Part 2; Vol 2; Appendix 3.8.

12. Ayurvedic Pharmacopeia Of India; Government Of India, Ministry Of Health And Family Welfare Department Of Ayurveda, Yoga \& Naturopathy, Unani, Siddha And Homoeopathy, New Delhi 2008; E Book; Part 2; Vol 2; Appendix 2.2.10.

13. Ayurvedic Pharmacopeia Of India; Government Of India, Ministry Of Health And Family Welfare Department Of Ayurveda, Yoga \& Naturopathy, Unani, Siddha And Homoeopathy, New Delhi 2008; E Book; Part 2; Vol 2; Appendix 2.2.3.

14. Ayurvedic Pharmacopeia Of India; Government Of India, Ministry Of Health And Family Welfare Department of Ayurveda, Yoga \& Naturopathy, Unani, Siddha And Homoeopathy, New Delhi 2008; E Book; Part 2; Vol 2; Appendix 2.2.4.

15. Svehla G Vogal's Qualitative Inorganic Analysis 7th Edition, Pearson Education Ltd.New Delhi,2002, p 227

16. Sadanand Sharma, Rasatrangini, Edited By Pt.Kashinath Shastri, Delhi, Motilal Banarasidas, Reprint 2004; Chapter 10/72-73,p 234

17. Karunanidhi Sharma, Shweta Paul, Sanjay Kumar, Dhiraj Singh Rajput, Pharmaceutical Study Of Trivanga Bhasma, Annals Ayurvedic Med. 2019; 8 (3-4) p 80-93

18. Bhatt GK, Prathama Adhyaya. In Tripathi I, Editor. Rasendra Sara Samgraha, Varanasi, Chaukhambha Orientalia, 2014, Verse No.322-324,p83

19. Bhatt A, Bajaj N \& Kashyap CP. Effect Of Number Of Puta On Particle Size Of Vang Bhasma International Ayurvedic Medical Journal. July, 2017. 5(7). p 2372-77

20. Pankaj Rai,Standard Manufacturing Process Of Abhraka Bhasma - A Pharmaceutical Study, Unique Journal of Ayurvedic And Herbal Medicines, MayJune 2015, 03 (03)

21. Pankaj Rai,Standard Manufacturing Process Of Abhraka Bhasma - A Pharmaceutical Study, Unique Journal of Ayurvedic And Herbal Medicines, May-June 2015, 03 (03)

22. Nandurkar Vishal Marotrao. Pharmaceutical and Analytical Study of Abhrak Bhasma. AYUSHDHARA, 2020.p 2958-2963.

23. Pankaj Rai, Standard Manufacturing Process Of Abhraka Bhasma - A Pharmaceutical Study, Unique Journal of Ayurvedic And Herbal Medicines, May-June 2015, 03 (03) 